\title{
Hvad er religion i Danmark 2014?
}

\author{
NIELS REEH
}

ENGLISH ABSTRACT: By an analysis of the Danish Humanist Society and the Danish Atheist Society, the aim of this contribution is to consider one aspect of the borderland of the Danish model of religion. On the basis of a relational approach to the study of religion, I conclude that the Humanist Society from an analytical point of view is a religion while the Atheist Society is not. In this manner, the Humanist Society should be regarded as part of the Danish model of religion while the Atheist Society should not. Therefore, it may be argued that the borderland of the Danish model of religion is located between these two organisations.

DANSK RESUMÉ: Dette bidrag undersøger en del af den danske religionsmodels grænseflade gennem en analyse af foreningerne Dansk Humanistisk Samfund og Ateistisk Selskab. På baggrund af et relationelt religionsbegreb konkluderes det, at $\mathrm{Hu}$ manistisk Samfund analytisk set er en religion og dermed en del af den danske religionsmodel. Med hensyn til Ateistisk Selskab konkluderer analysen, at denne forening analytisk set ikke er en religion men snarere en religionspolitisk forening. Ateistisk Selskab er dermed ikke en del af den danske religionsmodel. Den danske religionsmodels grænseflade kan dermed siges at befinde sig imellem disse to organisationer.

KEYWORDS: Definition of religion; humanism; religious survival units; mosaic distinction

Titlen på temanummeret Den danske religionsmodels grænseflade og altså begrebet den danske religionsmodels grænseflade har givet mig anledning til en (gen)overvejelse af spørgsmålet, hvad en religion er i en nutidig kontekst? Jeg vil tage udgangspunkt i det første spørgsmål, idet definitionen af religion har voldt betydelige vanskeligheder inden for den religionsvidenskabelige forskningshistorie (Lincoln 2006; Riesebrodt 2010). Man kan naturligvis indvende, at diskussionen af religionsbegrebet er overflødig, da de fleste med udgangspunkt i hverdagssproget formodentlig har en relativ klar opfattelse af, hvad religion indebærer. Jeg vil imidlertid argumentere for, 
at dette hverdagssprog er et problematisk udgangspunkt for en akademisk beskæftigelse med religion. Vi kan eksempelvis ikke uden videre være sikre på, at vores hverdagssprog formår at favne alle religioner (Reeh 2013). Endelig er der selve begrebet religionsmodel, der minder om økonomers begreb om f.eks. en arbejdsmarkedsmodel. I en dansk sammenhæng implicerer religionsmodellen en stor grad af statslig regulering, også selvom denne regulering i nogle tilfælde giver sig udslag i en bevidst ikke-indblanding. Begrebet religionsmodel peger således på, at religion ikke er et uafhængigt fænomen, men må forstås og analyseres i sammenhæng med den statslige regulering og samfundet i sin helhed. I det følgende vil jeg undersøge to grupperinger, der befinder sig omkring den danske religionsmodels grænseflade, nemlig Humanistisk Samfund og Ateistisk Selskab.

\section{Hvad er religion, og hvordan ved vi, hvad det er?}

Inden for religionsvidenskaberne har forskere siden fagenes grundlæggelse forsøgt at nå frem til en universel religionsdefinition. Ideen bag en religionsdefinition er, som religionshistorikeren Armin W. Geertz korrekt har gjort opmærksom på, en induktiv videnskabsopfattelse. Det vil sige, at "man gennem et tilstrækkeligt antal iagttagelser [af forskellige religioner] ... er i stand til med rimelig sikkerhed at drage universelle slutninger"'" (Geertz 1997, 145). Armin Geertz' artikel søger at gøre op med de empiristiske tilgange til studiet af religion og peger på brugen af induktion som et vigtigt og ofte forekommende problem i den religionsvidenskabelige arbejdsproces. Som det indirekte fremgår af ovenstående citat, anskues religioner ofte som fænomener, der eksisterer som selvstændige fænomener i-sig-selv, idet de gøres til genstand for en iagttagelse, hvorefter man med et tilstrækkeligt antal observationer kan lave et udkast til en definition, der kan beskrive alle observationerne. Denne tilgang har sin rod i den fænomenologiske tradition, der i det meste af det 20. århundrede var en dominerende tilgang inden for religionshistorien. Inden for religionssociologien er religion ofte blevet analyseret som et produkt af samfundet. Et eksempel på dette ses i Emile Durkheims Les formes élémentaires de la vie religieuse fra 1912 (Durkheim 1912). Det vigtige i denne sammenhæng er, at Durkheim netop undlader at tale om flere religioner inden for et samfund, men kun om religion. Denne tankefigur er ikke begrænset til Emile Durkheim, men er i vidt omfang overtaget af f.eks. den religionssociologiske forskning i sekularisering, hvor det, der skal beskrives, er "the decline of religion" (Tschannen 1991; Bruce 2011). Inden for den durkheimiansk inspirerede forskning har man som en konsekvens af det teoretiske udgangspunkt ikke beskæftiget sig så meget med det forhold, at religioner forholder sig til hinanden (Finke \& Stark 1992; Assmann 1997; Riesebrodt 2010; Reeh 2013a). En konsekvens af det durkheimianske perspektiv på religion er, at forskningen kan være tilbøjelig til at miste blikket for, at der er en interreligiøs dynamik mellem religionerne i feltet af religioner. 
Den inter-religiøse dynamik er efter min opfattelse af afgørende betydning, da den har været medvirkende til, at begrebet religion via forskydninger i feltet af religioner har ændret sig ganske væsentligt i det historiske forløb (Reeh 2012; Reeh 2013a). En måde hvorpå man kan iagttage ændringerne i religionsbegrebet er naturligvis via en begrebshistorisk analyse (Feil 1986; Kippenberg 2002). Det latinske religio, der formodentlig er oprindelsen til det moderne ord religion, betød noget i retning af ærbødighed overfor guderne og en nøje overholdelse af ritualerne. Religio var således nærmere en individuel praksis og attitude. Det dækkede ikke over en organisation, en etik eller en trosbekendelse. Dette ændrede sig med kristendommens fremkomst, da denne netop stod stærkt med hensyn til organisation, etik og trosbekendelse. En anden metode til fremdragelse af den historiske forandring i religionsbegrebet er brugen af ordet ateisme, der er modsætningen til teisme og ofte også til religion i en dagligdags betydning. Eksempelvis måtte den kristne Justin Martyr forsvare sig selv og andre kristne i det 2. århundrede mod anklager netop for ateisme (Barnard, ed., 1997).

I sammenhæng med temaet om den danske religionsmodels grænseflade er ateisme et interessant begreb, da det netop ofte opfattes som det modsatte af religion. I modsætning til i det 2. århundrede blev situationen vendt om, efter at kristendommen blev den dominerende religion i Europa. I det 18. århundrede var det nu ikke længere de kristne, der var under anklage for ateisme og altså hinsides religion, men derimod kættere og frafaldne fra den kristne kirke. Går vi videre frem til i dag, kan vi ydermere se, at ateisme nu ikke kun bruges polemisk mod andre men også som en selvbetegnelse. Historisk set har brugen af begrebet ateisme og dermed religionsbegrebets grænse varieret ganske betydeligt. Denne grænse har været afhængig af, hvem der dominerede det religiøse landskab.

I det 2. århundrede blev ateisme brugt om kristendommen, og i dag bruges det som modsætning til religion herunder kristendommen. På denne baggrund kan man rejse spørgsmålet, hvordan vi ved, hvad religion er, når religionsbegrebet hidtil har været afhængigt af de dominerende historiske strømninger i det europæiske religiøse landskab? Derudover har religionsvidenskabernes religionsbegreb også været omstridt, og det er blevet hævdet, at religionsbegrebet ikke bare er afhængigt af den europæiske religiøse tradition, men også af religionsvidenskabens egen "discourse of the day" (Stuckrad 2003, 258).

\section{Religionernes indbyrdes iagttagelse af hinanden}

Et hovedmoment i nærværende artikels argumentation er, at religiøse aktører reagerer og forholder sig til hinanden. Religioner er altså betinget og determineret af de andre signifikante religioner i religionens omverden eller miljø (Reeh 2013a). Som eksempler på en sådan inter-religiøs iagttagelse og den deraf følgende inter-religiøse dynamik kan nævnes, at Det Gamle Testamente forholder sig til kanaanærenes, hit- 
titternes og babyloniernes religioner. Det nye Testamente forholder sig til jødisk og særligt farisæernes religion. Koranen forholder sig til kristendommen, jødedommen, zarathustrismen (bogens folk) og de vantro. Mormonerne forholder sig til kristendommen, og den seneste tids spiritualitet forholder sig ofte til traditionel dogmatisk religion etc.

Som nævnt har religionsvidenskaberne haft svært ved at nå til enighed om, hvad religion er. Samtidig er religiøse aktører i stand til at iagttage og genkende en anden religion, når de møder en. Jeg foreslår, at denne iagttagelse og genkendelse også gælder, selv om den anden religion ikke selv opfatter sig som religion (Reeh 2013a, Reeh 2013b). Dette er også tilfældet, selvom den iagttagende religiøse aktør søger at udgrænse den konkurrerende religion som ikke-religion, og dermed som noget, der falder uden for det acceptable. Det afgørende her er, at den iagttagende religiøse aktør opfatter den anden som en konkurrent eller som en reel deltager i det felt af religioner, som den iagttagende religiøse aktør selv er en del af.

Efter min opfattelse ligger nøglen til et analytisk anvendeligt religionsbegreb, der kan indfange dynamikken mellem religioner, i dette 'vi' eller 'os', der modstilles et 'de' eller 'dem'. På baggrund af de kollektivt socialt konstruerede vi'er, er det nemlig muligt at analysere disse uden på forhånd at sige så meget om, hvad disse religiøse vi'er er. I stedet for at iagttage et stort antal religioner i sig selv vil jeg foreslå et relationelt perspektiv på religion (Reeh 2013a). Det vil sige et perspektiv, der tager udgangspunkt i, at religiøse aktører iagttager, genkender og reagerer på hinandens tilstedeværelse i et socialt felt. Dette sociale felt vil jeg i det følgende kalde feltet af religioner. Spørgsmålet er imidlertid, hvorfor alle religioner synes at forholde sig til mindst én signifikant religiøs anden. Som svar på det spørgsmål vil jeg foreslå et analytiske greb, nemlig at vi anvender den tyske sociolog Norbert Elias' begreb om 'overlevelsesenheder' inden for studiet af religion (Elias 1978. 2008; Reeh 2013a. 2013b). Begrebet overlevelsesenhed er Elias' statsbegreb, hvor staten er en enhed blandt andre lignende statslige enheder.

Thus the primary function of such an alliance is either physically to wipe out other people or to protect its own members from being physically wiped out. Since the potential of such units for attack is inseparable from their potential for defence, they may be called 'attack-and-defence units' or 'survival units'. At the present stage of social development they take the form of nation-states. In the future they may be amalgamations of several former nation-states. In the past they were represented by city-states or the inhabitants of a stronghold. Size and structure vary: the function remains the same (Elias 1978, 138-9).

En afgørende pointe hos Elias er således, at staten må overleve i et miljø af andre potentielt fjendtlige stater. Elias' survival unit er således placeret i, hvad man med Bourdieus terminologi kunne kalde et socialt felt, idet agenterne også i Bourdieus optik konkurrerer med hinanden. Forskellen på Elias og Bourdieu er imidlertid, at 
Elias' overlevelsesenhed er en kollektiv enhed, hvorimod Bourdieus agenter er individer (Bourdieu 1990). Når Bourdieu taler om det religiøse felt, består dette således af individuelle aktører internt i religionens eget felt (Bourdieu 1989). Jeg foreslår med andre ord at anskue religioner som kollektive religiøse overlevelsesenheder, der søger at overleve i det miljø, de er placeret i. Dette miljø er reguleret af staten eller den statslige overlevelsesenhed. Dette regulerede miljø eller felt af religioner udgør den danske religionsmodel.

\section{Feltet af religioner i Danmark 2014 - hvor går grænsen?}

Hvis vi nu vender os mod feltet af religioner inden for den danske religionsmodel, er denne naturligvis først og fremmest karakteriseret ved, og domineret af, folkekirken, hvor størstedelen af danskerne er medlemmer. Denne del af den danske religionsmodel er behandlet andetsteds (Christoffersen et al. 2012). I det følgende skal det imidlertid handle om to grænsefænomener, nemlig Humanistisk Samfund og Ateistisk Selskab.

Humanistisk Samfund blev stiftet i august 2008 (Humanistisk Samfund 2014a). I årene inden havde der fundet en diskussion sted i ateistiske internetfora om, hvorvidt ateister burde indføre ritualer. Et eksempel på dette ses af følgende citat fra en ateistisk blogpost fra 2007, hvor bloggeren Regicollis eksempelvis skrev:

Jeg tager sikkert ikke fejl når jeg antager at mennesker til enhver tid har haft brug for ritualer for at markere begivenheder i livet. ... Hidtil har de religiøse fået lov til at sætte sig på ritualerne.... Hvis vi ønsker at få folk til at melde sig ud af statskirken ... er vi nødt til at stille noget i stedet for det, folk får i statskirken. ... tit er folk medlemmer fordi statskirken rent faktisk giver nogle rituelle rammer omkring livets begivenheder. Jeg tror at hastigheden af statskirkens medlemsflugt kunne sættes op, hvis man i stedet for næsten ikke at have adgang til nogle faste ritualer, som alternativ til statskirken havde et sæt sekulære ritualer ... Behovet for det rituelle er reelt, og det er noget vi som ateister bør overveje (Regicollis 2007).

I citatet fremføres to argumenter for at indføre ritualer: at mennesker har brug for ritualer til at markere begivenheder i livet, og at indførelsen af sekulære ritualer vil medvirke til øget medlemsflugt i folkekirken. Det sidste argument kan ses som en pendant til f.eks. kristen mission, da ritualerne blandt andet indføres for at tiltrække flere medlemmer. Den ovenfor citerede blogger stod ikke alene med sit synspunkt. Året efter i 2008 blev Humanistisk Samfund stiftet i København. På det stiftende møde sagde en af hovedkræfterne bag initiativet og den kommende formand Dennis Nørmark blandt andet følgende:

Et spørgsmål som jeg vil starte med: Er dette ikke bare en ny gruppe af ateister. ... Det her med ateisme, det er noget, vi hele tiden skal forholde sig til... Da ateisme konstant 
skal ... finde sig i først at skulle definere sig som en modsætning til et eller andet. Det gik op for mig: det gider jeg ikke mere! $\mathrm{Nu}$ vil jeg prøve sammen med de andre her at definere noget der lidt mere positivt. Jeg hørte fornylig et foredrag af Phil Zuckerman. ...En af de ting han sagde...: If you use that much energy fighting something - you are still dancing with it (Nørmark 2008).

Af dette citat og i en del andre passager i talen ses det dog, at Dennis Nørmark var særdeles optaget af, hvordan man skulle forholde sig til religion. Dennis Nørmark fortsatte med at forholde sig til og distancere sig fra en vigtig anden for Humanistisk samfund, nemlig de danske ateistiske foreninger:

Hvis det bare hele tiden handler om, at man bare mødes og siger, at Gud ikke findes,... så er der ikke sket så meget mere ... Det handler om for mig at definere noget mere positivt...Dermed ikke sagt at jeg ikke i mit arbejde udfordrer og kritiserer religion... Hvis vi bare bliver ved med at være ateister, så opererer vi på de religiøses betingelser. ... så er det dem, der nærmest bliver vores eksistensberettigelse. ... Det er derfor, vi i dag stifter humanistisk samfund - ikke for at bekæmpe religion men for at blive fri for religion ... fordi det er det, vi grundlæggende er - fri for religion. ... Vi er sådant set mennesker, og det andet det er noget, der kommer til. Frihed fra religion det er en menneskeret, og det er faktisk også en FN beskyttet menneskeret, og i Danmark overtrædes denne regel hver eneste dag. Det er en af ting, som er grunden til at vi - også udover at skulle lave de ting, de ceremonier, som der er meget fokus på, selvfølgelig også har en politisk dagsorden med det, vi laver (Nørmark 2008).

Det var formodentlig blandt andet denne kritik, der efterfølgende medførte et ret køligt forhold mellem ateister og humanister, på trods af at de var enige om at afvise eksistensen af Gud, det transcendente etc. I citatet henviser Dennis Nørmark til FN og menneskerettighederne. Den danske stats ratificering af menneskerettighederne er således en del af den danske religionsmodel, idet det er blevet et våben som religioner kan anvende mod hinanden og staten i deres indbyrdes kamp. Denne kamp må ses som en kamp om, hvordan samfundet skal indrettes. Religioner påvirker naturligvis det samfund, de befinder sig i og som for eksempel kristne og muslimer har historisk set påvirket de samfund, hvor de har haft styrken til det. På tilsvarende måde kan man således her se, at Humanistisk Samfund kæmper (missionerer) for et mere sekulært samfund. I talen fortsatte Dennis Nørmark med at forholde sig til andre religioner eller rettere med at argumentere for, at man burde undgå netop denne forholden sig til de andre religioner. Efter at have opholdt sig en del ved forholdet til andre religioner og især kristendommen sluttede han af med et udkast til, hvad man kunne kalde en humanistisk trosbekendelse:

Så jeg anerkender ikke, at vi skal definere os selv negativt - i forhold til noget andet. Fordi religion er ikke noget, der skal vælges bevidst fra, men noget der skal vælges bevidst til. ... jeg er et menneske. Og som menneske fødes jeg uden religion. Jeg er humanist, og det betyder, at jeg tror på, at det mest fantastiske, virkelige, enestående, gode, 
utrolige, beundringsværdige, interessante, det er at være menneske et virkeligt menneske. Jeg tror på, at mennesket fungerer ganske udmærket, ja faktisk mener jeg, det fungerer en lille smule bedre uden religion, ja i hvert fald ved jeg, at jeg selv gør det... Religioner er noget, mennesker opfinder, mennesket som det er i sig selv er uden religion (Nørmark 2008).

Et afgørende moment for Nørmark var med andre ord, at Humanistisk Samfund ikke skulle definere sig selv negativt i forhold til noget andet. Resultatet af mødet blev, at Humanistisk Samfund blev stiftet og definerede sig selv på følgende måde:

Stk. 2. ... Humanisme er et demokratisk og etisk livssyn, som bekræfter det enkelte menneskes ret til og ansvar for at forme sit eget liv og give det mening. Den står for opbygning af et mere menneskevenligt samfund gennem en etik, som er baseret på menneskelige og andre naturlige værdier og styret af fornuft og frie valg gennem menneskelige evner og muligheder. Den er ikke teistisk og afviser overnaturlige forklaringer (Humanistisk Samfund 2014b).

Trods det forhold at Dennis Nørmark eksplicit ikke ville definere sig selv negativt i forhold til noget andet, er det netop resultatet, idet foreningen i citatet ovenfor beskriver sig selv som 'ikke teistisk og afviser overnaturlige forklaringer'. Den sociale logik gør det med andre ord vanskeligt at afgrænse sig selv uden at definere, hvad man ikke er. På samme måde som kristne kirker igennem det historiske forløb har trukket et skel eller en distinktion mellem sig selv og andre i deres trosbekendelser, afviser Humanistisk Samfund her de signifikante andre religioners tro (Se også Reeh 2013). Foreningen har i dag omkring 500 medlemmer.

\section{Hvad kæmper religionerne om?}

Jeg har tidligere foreslået at beskrive religioner som religiøse overlevelsesenheder, der er placeret i et miljø, hvor de søger at overleve (Reeh 2013a; 2013b). Dette miljø er den danske religionsmodel, der er reguleret af den danske stat. Ved at hævde at religioner er overlevelsesenheder, har jeg imidlertid blot sagt, at religioner forholder sig til hinanden på en bestemt måde, idet de er placeret i et socialt felt. Det er imidlertid ikke nok at sige, at religioner forholder sig til hinanden. Ser vi på den del af Dennis Nørmarks tale, hvor han fremlægger sin trosbekendelse, er det ikke kun forholdet til den signifikante religiøse anden, der er afgørende:

Jeg tror på, at mennesket fungerer ganske udmærket, ja faktisk mener jeg, det fungerer en lille smule bedre uden religion, ja i hvert fald ved jeg, at jeg selv gør det.... Og humanisme hvad er så det?.. Det handler om at lave et livssyn, et værdigrundlag og ikke bare definere sig negativt. ... Det er troen på menneskets værdighed... mennesket er et mål, det er ikke et middel ... det betyder også, at mennesket ikke er en del af en eller anden større plan, der er ikke et eller andet vi skal, andet end, at vi skal være os selv, det er troen på, 
at vi rummer det gode såvel som det onde, det onde vi laver, os mennesker, det opstår i mangel på omtanke, men vi er faktisk født med rationalitet, med fornuft, vi er ikke født syndige, skamfulde, vi er født som en kompleks art, der kan både det onde og det gode, det handler for os om at tænke os om så vi undgår at lave så meget af det onde som muligt, perfekte bliver vi aldrig nogensinde, sådan er det, det er et vilkår vi lever under, sådan er det når man er produktet af evolution og ikke produktet af en skabelse. Så tror jeg på, at Humanisme også handler om at tro på fremtiden, ikke på en armageddon, hvor det hele på et eller andet tidspunkt bryder sammen, men rent faktisk troen på, at vi kan forbedre tingene, blive dygtigere, hvor vi kan gøre det bedre, det hele er ikke forudbestemt, ... det er os der afgør hvad der skal ske, mennesket rummer ondt, men grundlæggende er vi moralske og etiske, vi skylder intet overnaturligt væsen at opføre os ordentligt, vi skylder det overfor hinanden, først fremmest derfor er vi moralske og etiske væsener pga. vores natur ikke fordi nogen så at det var godt...(Nørmark 2008, mine fremhævelser).

I denne del af talen slår Nørmark således sin antropologi fast: Det sande menneske er uden religion, og mennesket fungerer bedre uden religion. Mennesket er ikke en del af en større plan, men er altings mål. Det ondes eksistens i verden skyldes mangel på omtanke og at mennesket ikke bruger den fornuft og rationalitet, som det er født med. Her synes Nørmark at mene, at religion kan lede til mangel på omtanke og dermed ondskab. Menneskets oprindelse er evolution og ikke skabelse. Humanisme indebærer for Nørmark ikke kun en antropologi, men også en fremtid som ikke består i en forudbestemt plan, men i at mennesket kan "gøre det bedre" og dermed perfektionere sig selv. Afslutningsvis i dette stykke slår Nørmark fast, at mennesket har en moralsk og etisk natur, fordi vi skylder vores næste at opføre os ordentligt og ikke som følge af et guddommeligt påbud. Med denne trosbekendelse leverer Nørmark således en modmyte dels til folkekirkens kristne frelseshistorie. Jeg har i en tidligere artikel foreslået, at religioner kan opfattes og analyseres som selvforsvarende kollektive enheder, der søger at opretholde en sandhed inklusiv deres fortælling om den ultimative oprindelse, nutid og den ultimative fremtid som absolut Sand (Reeh 2013a). Dette sker gennem to religionshistoriske grundbegreber, nemlig myte og ritual. Myter bliver i dette perspektiv en diskurs, der er centreret om forholdet mellem oprindelse (f.eks. kosmogoni), nutid og fremtid (eskatologi). Ritualer forstås som praktikker, der er centreret om at gribe ind i fremtiden, og som dermed af ritualdeltagerne hævdes at have det, religionshistorikeren Jørgen Podemann Sørensen har kaldt rituel effikacitet (Sørensen 2001).

\section{Humanistisk Samfunds ritualer}

Som nævnt ovenfor var en bevæggrund bag indførelsen af humanistiske ritualer, at man ville konkurrere med folkekirken og tilbyde folk det, som en del danskerne 
kommer i kirken for, nemlig rituelle markeringer af livets store overgange. Det kan imidlertid synes paradoksalt, at ateistiske og humanistiske organisationer har udviklet ritualer eller ceremonier. Hvis man mener, at der ikke er en gud, hvorfor så et ritual? Ser man imidlertid på, hvad Humanistisk Samfund selv skriver om deres ceremonier f.eks. i bogen En humanistisk antologi (Jensen 2008), er der tale om meningsskabende handlinger:

Humanismen som livssyn setter mennesket i sentrum og fremhever den enkeltes menneskeverd, selvstendighet, ukrenkelighet og iboende verdighet. Humanismens virkelighetsforståelse, etikk og menneskesyn er basert på fornuft og erfaring, rasjonell tenkning, empati og medmenneskelighet. Humanistisk gravferd er en verdslig og høytidelig seremoni på et humanistisk grunnlag til minne om avdøde. Det velges gjerne når den avdøde selv ønsket det, eller når de pårørende mener slik gravferd er best egnete form for høytidelighet. For mange handler valg av gravferdsform, i den grad familien faktisk har et reelt valg, om at vise respekt overfor avdødes uttrykte livsholdning og redelighet overfor øvrig familie og andre som kjente avdøde og som visste hva avdøde sto for (Tufte 2007, 68).

Som citatet illustrerer, er mening i denne sammenhæng helt afgørende. Man kan måske sammenfatte det ved at sige, at ritualet er en højtidelig fejring af det individuelle menneske set $\mathrm{i}$ et humanistisk perspektiv. Umiddelbart kan man hævde, at dette ikke er et religiøst ritual, da ritualet eller ritualerne ikke gør noget ved den afdøde, og at det dermed ikke har en rituel effikacitet. Ser man på den citerede tekst må man dog sige, at ritualet skal mindes og vise respekt overfor afdøde. Ritualets objekt er med andre ord ikke den afdøde, men derimod de pårørende. Effikaciteten er med andre ord flyttet fra den afdøde til de pårørende. Her må det indskydes, at Humanistisk Samfunds begravelsesritual har betydelige ligheder med en del ritualer i den kristne tradition, ikke mindst Calvins reformerte nadverlære (Calvin 2007, 388ff). I modsætning til den katolske og den lutherske nadver er den reformerte nadver et rent opbyggeligt mindemåltid. Som i Humanistisk Samfunds begravelsesceremoni ligger ritualets effikacitet i den effekt, som ritualet har på deltagerne. Det forhold, at ritualets effekt ligger i deltagernes erindring eller minde, er ikke et særkende ved Humanistisk Samfunds ritualopfattelse, men findes således også hos Calvin.

\section{Er Humanistisk Samfund en religion (analytisk set)?}

Hvis vi nu ser bort fra vores dagligdags opfattelse af, hvad en religion er, og skal afgøre, om Humanistisk Samfund analytisk set er en religion eller ej, kan vi sige, at Humanistisk Samfund har mange fællestræk med andre religioner.

Først og fremmest synes Humanistisk Samfund primært at forholde sig til andre religioner. På samme måde som f.eks. kristendom og islam har Humanistisk Samfund etableret det, religionshistorikeren Jan Assmann har kaldt en mosaisk distinkti- 
on, idet man afviser andre religioners sandhed (Assmann 2010). Dermed er Humanistisk Samfund en del af feltet af religioner i Danmark eller den danske religionsmodel, da foreningen indgår i dette sociale felt på linje med andre religioner.

For det andet har Humanistisk Samfund udarbejdet deres eget organiserede bud på den ultimative sandhed. Dette kommer blandt andet til udtryk i, at de har etableret ritualer og autoriseret ceremoniledere til at forestå disse. Dermed kan vi sige, at Humanistisk Samfund har samme interne funktionelle arbejdsdeling som andre religioner. Dertil kommer, at Nørmark i sin humanistiske trosbekendelse opridser en skitse til en modmyte, der modstilles den kristne frelseshistorie. Samlet set peger de nævnte forhold efter min opfattelse klart i retning af, at Humanistisk Samfund udmærket kan analyseres som en del af den danske religionsmodel og at Humanistisk Samfund dermed analytisk set er at betragte som en religion.

\section{Ateistisk Selskab}

Hvis Humanistisk Samfund analytisk set er en religion eller i hvert fald en funktionel ækvivalent til en religion, melder et mere besværligt spørgsmål sig med hensyn til Ateistisk Selskab. Ser vi på Ateistisk Selskab i forhold til Humanistisk Samfund, er der både ligheder og en række slående forskelle mellem de to foreninger. Ifølge vedtægterne er Ateistisk Selskabs formål følgende:

$\S 2$ stk. 1. at være en forening for ikke-troende, 2. at arbejde for en total adskillelse mellem religion og stat, således at alle mennesker ligestilles uanset deres religiøse synspunkter og verdensbillede, 3. at oplyse offentligheden om det ateistiske synspunkt og derved mindske fordommene imod ateister, 4 . at opfordre folk til at tænke kritisk og selvstændigt om liv og eksistens, 5 . at støtte dem, der i en overvejende religiøs verden ønsker at forholde sig til deres tvivl og skepticisme overfor religion og anden overtro, 6 . at arbejde for udbredelsen af et naturalistisk verdensbillede, der bygger på kritisk tænkning og den videnskabelige metode (Ateistisk Selskab 2014a).

Ateistisk Selskab etablerer her en distinktion, der er funderet på ikke-tro og en bekendende ikke-bekendelse. Et andet lighedstræk mellem Humanistisk Samfund og Ateistisk Selskab er, at man dels søger at af-kristianisere det danske samfund, dels ønsker at oplyse om og udbrede eller missionere for foreningens verdensbillede.

Der er dog også en væsentlig forskel mellem de to foreninger, idet Humanistisk Samfund som nævnt har de humanistiske ritualer som et centralt punkt. Ateistisk Selskabs virke ser derimod ud til primært at bestå i at vedtage religionspolitiske resolutioner (Ateistisk Selskab 2014a). På Ateistisk Selskabs hjemmeside finder man dog en enkel henvisning til ceremonier, idet der under punktet 'Livets afslutning' er en række forslag til, hvad man kan gøre, når en er død. Her foreslås det blandt andet, at man kan donere sin krop til videnskaben (Ateistisk Selskab 2014b). Derudover nævnes det også som en mulighed at få afholdt en ikke-religiøs ceremoni ved begra- 
velsen. Her henviser siden til firmaet Livsceremonier.dk, der ejes af en forhenværende præst i folkekirken og en psykolog. Man kan derfor sige, at Ateistisk Selskab nøjes med at komme med forslag, som er i overensstemmelse med foreningens distinktioner i forhold til andre religioner, og at de har udliciteret ceremonidelen til en anden aktør.

Det sociale felt af religioner består i det fremførte teoretiske perspektiv af religiøse overlevelsesenheder, som kollektivt etablerede praktikker (den ultimative sandhed), der dels er centreret om oprindelse, nutid og fremtid, dels afviser andre bud på den ultimative sandhed. Her må man konkludere, at Ateistisk Selskab er et grænsetilfælde.

På den ene side hævder Ateistisk Selskab en ultimativ sandhed, som udgøres af en bestemt fortolkning af naturvidenskabelige resultater, og man afviser kategorisk andre religioners sandhed. I forlængelse heraf foreslår foreningen eksempelvis også, at medlemmerne skal donere deres afdøde krop til videnskaben. Man kan således hævde, at dette kan ses som en praksis, der er med til at opretholde et bestemt verdensbillede og gribe ind i fremtiden ved at stille kroppen til rådighed for fremtidens videnskabelige landvindinger. På den anden side vil jeg imidlertid mene at det forhold, at Ateistisk Selskab ikke selv har organiseret deres egne ritualer for livets overgange, og at de dermed ikke har samme interne arbejdsdeling som en 'traditionel' religion med en autoriseret præst/ceremonimester (som er tilfældet med Humanistisk Samfund) peger på, at det formodentlig vil være mere korrekt at anskue Ateistisk Selskab som en religionspolitisk forening. Ateistisk Selskab er dog ganske tæt på at være en religion, da deres primære signifikante anden er religion og især kristendommen. Dette underbygges også af, at Humanistisk Samfund må ses som en knopskydning fra det ateistiske miljø, hvor en del medlemmer i årene inden 2008 fandt de eksisterende ateistiske foreninger utilfredsstillende (Nørmark 2008). Samlet set mener jeg derfor, at mens Humanistisk Samfund analytisk set er en religion og dermed en del af den danske religionsmodel, så peger ovenstående analyse på, at Ateistisk Selskab ikke er en religion, men snarere en religionspolitisk forening. Hvorvidt man vil regne en religionspolitisk forening som Ateistisk Selskab med til den danske religionsmodel er naturligvis et spørgsmål om, hvordan man definere begrebet religionsmodel. Hvis den danske religionsmodel betyder feltet af religioner i Danmark, er det imidlertid min opfattelse, at Ateistisk selskab ligger uden for den danske religionsmodels grænseflade.

\section{Afsluttende bemærkninger}

Målet her har været at give anledning til refleksion over grænserne i det religionsvidenskabelige religionsbegreb. Jeg har derfor givet et par eksempler på organisationer, der udkæmper en anerkendelseskamp i det danske felt af religioner, hvor man kan diskutere, om de ligger inden for eller uden for det religionsvidenskabelige reli- 
gionsbegreb. Efter min vurdering er Humanistisk Samfund analytisk set en religion, mens Ateistisk Selskab nærmere må betegnes som en religionspolitisk forening. Den danske religionsmodels grænseflade kan dermed siges at befinde sig imellem disse to organisationer. I et historisk perspektiv kan ateisme og humanisme anskues som religiøse distinktioner, der udvikles i en relation til den eller de eksisterende signifikante religiøse andre i feltet af religioner. Religionshistorien kan således anskues som en dynamisk udvikling af distinktioner, der negerer hinanden. Stiftelsen af Humanistisk Samfund er et eksempel på den inter-religiøse dynamik, der konstant afføder nye udviklinger og strømninger inden for såvel som på grænserne af den danske religionsmodel.

\section{LITTERATUR}

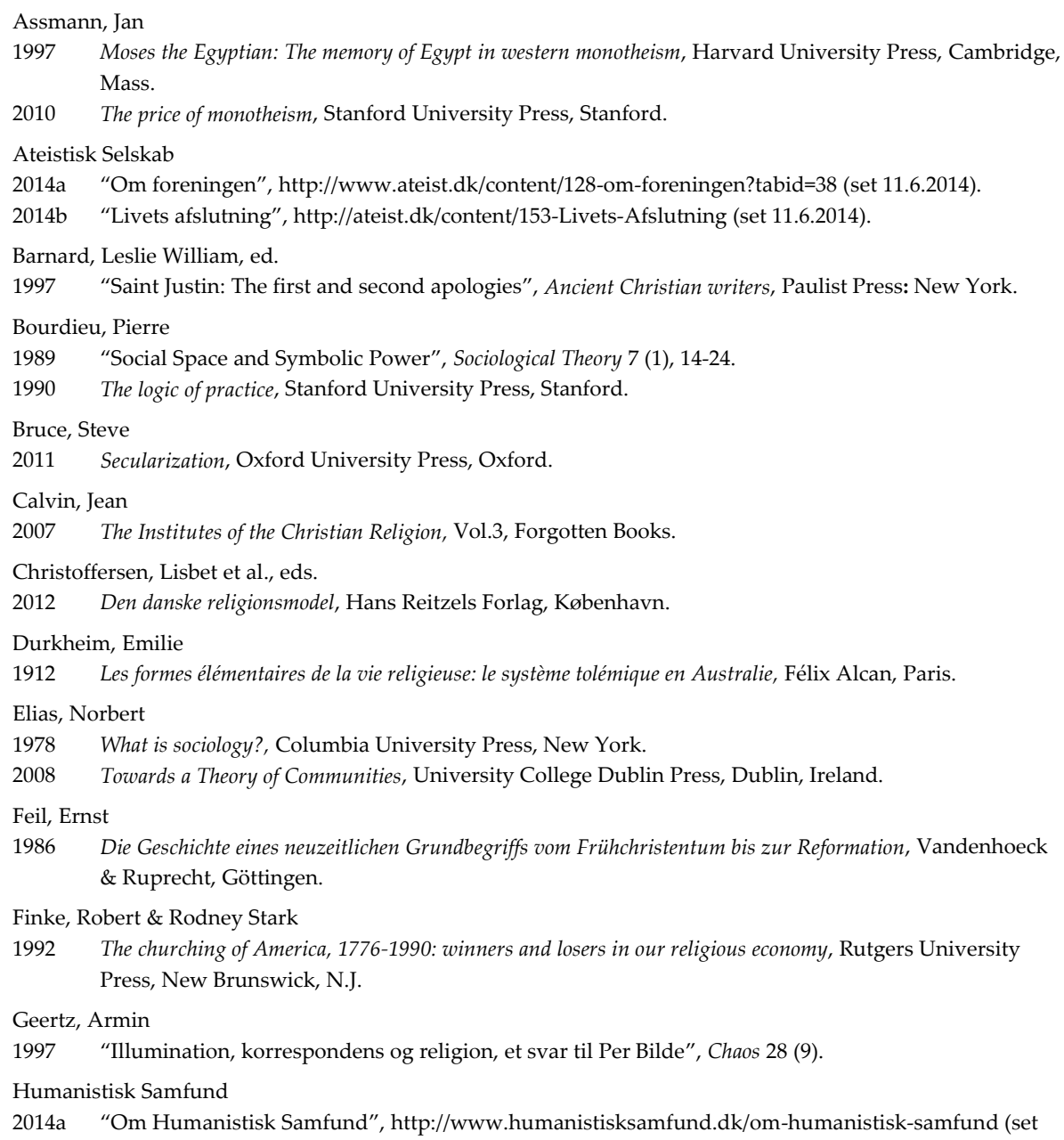


21.5.2014).

2014b "Humanistisk Sa0mfunds Vedtægter", http://www.humanistisksamfund.dk/om-humanistisk samfund/vedtaegter (set 21.1.2014)

Kippenberg, Hans Georg

2002 Discovering religious history in the modern age, Princeton University Press, Princeton.

Livs Ceremonier.dk

2014 “Livs Ceremonier, http://www.livsceremonier.dk (set 21.1.2014).

Lincoln, Bruce

2006 Holy terrors: thinking about religion after September 11, University of Chicago Press, Chicago.

Nørmark, Dennis

2008 "Tale ved stiftelsen af Humanistisk Samfund", http://www.youtube.com/watch?v=eM60TdXCULM (set 21.1.2014).

Reeh, Niels

2012 "Om den danske stats religionsundervisning fra enevælden til new public management", Den danske religionsmodel, Lisbet Christoffersen et al, eds., Hans Reitzels Forlag, København.

2013a "A Relational Approach to the Study of Religious Survival Units", Method and Theory in the Study of Religion 25.

$2013 b$ "The Field of Religions in Norwegian Pluralist Society", Giuseppe Giordan \& William Swatos, eds., Testing Pluralism, Brill, Leiden, 175-192.

Regicollis

2007 "Behov for ritualer", http://debat.ateist.net/showthread.php?t=3692 (set 21.1.2014)

Riesebrodt, Martin

2010 The promise of salvation: a theory of religion, University of Chicago Press, Chicago, Ill..

Sørensen, Jørgen Podemann

2001 "Det rituelle nulpunkt", Religionsvidenskabeligt Tidsskrift 39, 3-13.

Stuckrad, Kocku von

2003 "Discursive Study of Religion: From States of the Mind to Communication and Action", Method E Theory in the Study of Religion 15, 255-271.

Tschannen, Olivier

1991 "The Secularization Paradigm: A Systematization", Journal for the Scientific Study of Religion 30 (4), 395-415.

Tufte, Vinjar Kvaale, Yngvild

2007 "Humanistisk gravferd i Norge", In: Erik Bartram Jensen, ed., At leve og dø uden religion, Forlaget Camille, Viborg.

Niels Reeh, ekstern lektor, ph.d. Institut for Tværkulturelle og Regionale Studier, Københavns Universitet 
